\title{
BLOOD QUANTUM IN SCOTT MOMADAY'S THE NAMES
}

Guillermo Bartelt ${ }^{\mathrm{i}}$

California State University, Northridge, USA

\begin{abstract}
:
The semiotics of blood quantum in Scott Momaday's memoir, The Names, is interpreted regarding its role as a signifier of American Indian survival and resistance in the context of his introspective concept of mythopoetic blood memory.
\end{abstract}

Keywords: American Indian literature, Indian blood laws, racial memory, Survivance

\section{Introduction}

The American Indian novelist and poet N. Scott Momaday achieved early success with the publication of House Made of Dawn, which was awarded the Pulitzer Prize for Fiction in 1969 and which has been upheld as the first major work in what became known in American letters as the "Native American Renaissance." As a follow-up, Momaday's editor at Harper and Row, Frances McCullough, who was fascinated by his unusual background, encouraged him "to write a sort of autobiography about growing up Indian," which might also illuminate some of the seemingly opaque Native symbolism in his novel (Schubnell 1985, 168). Though the next few years found him busy pursuing other projects, Momaday eventually published The Names: A Memoir, in which he traces his lineage and recalls his experiences growing up among Indian tribes in the American Southwest of the 1940s and 50s. Since memoirs tend to chronicle selective and embellished memory, they bear resemblance to what sociologists call the "presentation of self," a dramaturgical perspective that views individuals as attempting to control the impressions others form about them (Goffman 1956). In Momaday's memoir, the symbolic and imaginative identification with his Indian roots takes center stage in the creation of a personal myth which strives to impress upon others the gestalt he desires for himself.

The memoir sets out on a search of four generations of Momaday's paternal Indian as well as his maternal Anglo-American ancestors, then tells of his birth in Oklahoma to Mayme Natachee Scott, of partial Cherokee descent, and to Alfred Morris Momaday, a full-blood Kiowa, and ultimately turns to the enthralling reminiscences of his childhood among Native peoples of the American Southwest. Since his parents were fortunate enough to secure employment during the Great Depression as teachers with the Indian Service, young Scott was given the rare opportunity of spending his formative years on several Indian reservations in Arizona and New

iCorrespondence: email gbartelt@prodigy.net, guillermo.bartelt@csun.edu 
Mexico, at a time when Native life was still traditional and was just beginning to be transformed by mainstream societal pressures. That exposure allowed Momaday to experience not only his father's Kiowa traditions of Oklahoma but also those of Southwestern tribes such as the Apache, Navajo, and especially Jemez Pueblo, where the family moved when Scott was twelve years old and where he lived until he had to attended off-reservation high schools. Thus, "[a]t Jemez," Momaday concludes his memoir, "I came to the end of my childhood" and to the point at which he began to find his way in mainstream American society (Momaday 1976, 160).

\section{Indian Blood}

Shortly before Frances McCullough suggested the autobiographical account of his Indian childhood, Momaday had already expressed to his mentor at Stanford University, Ivor Winters, the desire to write a non-fiction "evocation of the American landscape, informed by autobiographical elements," with the goal of creating an "indigenous book" (Schubnell 1985, 167). While the landscape of the American Southwest is certainly evoked in The Names, it is the "presentation of self" as an assertion of a Native identity that informs his discourse of indigeneity. Of the numerous strategies in effecting his "self-presentation," Momaday's insistence on the verbatim inclusion of a seemingly trivial document, his birth certificate, turns out to be very compelling in verifying his Indian bona fides.

"I also have in my possession a notarized document issued by the United States Department of the Interior, Office of Indian Affairs, Anadarko Area Office, which reads:

To whom it may concern:

This is to certify that the records of this office show that Novarro Scott Mammedaty was born February 27, 1934 at Lawton, Oklahoma and is of 7/8 degree Indian blood, as shown on the Kiowa Census roll opposite Number 2035. The official Government records further show that his father is Alfred Mammedaty and his mother is Natachee Scott.

By Act of June 2, 1924 (43 Stat. 253), all Indians born within the territorial limits of the United States were declared to be citizens of the United States." (Momaday 1976, 42)

The enrollment in a federally recognized tribe, based on blood quantum regulated by individual Indian nations, is without a doubt the most crucial criterion for claiming an Indian identity in the United States. Those who may profess Native ancestry but lack this basic requisite are not extended the services owed by government treaty obligations and may be regarded with suspicion by the "real Indians" as to the veracity of their pretentions. From the perspective of biological anthropology, however, the standard of blood quantum as used by the federal and tribal governments is patently pseudoscientific, a symptom of which reveals itself clearly in the odd arithmetic of Momaday's seven-eighth degree Indian blood quantum.

According to Momaday's "Genealogical chart" featured in the front matter of The Names, his mother, Mayme Natachee Scott, if she had been enrolled in a federally recognized tribe, would have been classified by the government as seven-eighth White and one-eighth Indian (Charles 2007, 29). Since she hailed from Kentucky and was allowed to attend a government-run 
boarding school for Indian students, Haskell Institute in Lawrence, Kansas, it is possible that she was enrolled in a tribe such as the Eastern Band of Cherokee Indians in North Carolina, which has accepted enrollments of members with as little as one-sixteenth degree of Indian blood quantum. In any case, a full blood Indian father and a one-eighth blood Indian mother do not produce a seven-eighth blood Indian offspring. However much biologically and especially arithmetically suspect, the fraction assigned to Momaday is socially significant in that his birth certificate bestows upon him the potentiality of engaging in the "self-presentation" of a near full blood.

Ironically enough, the time-honored notion of blood quantum is firmly embedded in the repugnant history of racial discrimination and anti-miscegenation laws dating back as far as the colonial era. Though not as severe as the one-drop rule suffered by individuals of African ancestry, Indian blood laws, such as those in Virginia, for example, were enacted to limit the civil rights of Native and mixed blood residents (Forbes 2021). In fact, as revealed by the postscript on Momaday's birth certificate, many such individuals were not even granted full citizenship until 1924. However, the irony of all ironies was that some of the leading families of Virginia descended from the union of the early Jamestown tobacco planter John Rolfe and his second

wife, Rebecca, more commonly known as Pocahontas, the daughter of the Powhatan chieftain Wahunsenacah. Thus was added the bizarre "Pocahontas Clause" to the Virginia Racial Integrity Act, which allowed a maximum Indian blood quantum of one-sixteenth without losing one's legal status as a white person (Tallbear 2003).

Regardless of how seemingly bizarre and pseudoscientific, the concept of blood quantum became rigidly entrenched in the Indian Reorganization Act of 1934. The federal government was determined to implement a legally "tight" definition for individuals to qualify for "Indian" status for the distribution of financial and other benefits guaranteed by treaties as well as for the sales of surplus reservation lands (Spruhan 2001; Thornton 1996). Before the Indian Reorganization Act, most tribes had not formally employed blood quantum rules; instead, membership had typically been determined by precedents which appealed to kinship, lineage, and family ties (Tallbear 2003). Since then, however, only a few tribes have managed to retain consanguinity criteria by relying on the questionable accuracy of older government enrollment records as a starting point. Yet, for the most part, tribes have had little choice but to adopt the federally mandated blood quantum construct as a guide in establishing their own standards for tribal membership.

\section{The Postindian Warrior}

The Anishinaabe (Chippewa) novelist and cultural critic Gerald Vizenor, in his groundbreaking work, Manifest Manners: Narratives on Postindian Survivance, contends that Indian survival in and of itself is a form of resistance against a hostile federal government as well as an abetting mainstream society that attempt to efface, or at least ignore, Native culture all together. Alluding to the continued legacy of Manifest Destiny and coining the portmanteau "Survivance," a blend of survival and resistance, Vizenor galvanizes Native writers to deflate and subvert stereotypical 
images of the "vanishing Indian" by embracing traditional culture and demonstrating its viability in contemporary contexts.

"The Postindian warriors of postmodern simulations would undermine and surmount, with imagination and the performance of new stories, the manifest manners of scriptural simulations and 'authentic' representations of the tribes in the literature of dominance." (Vizenor 1994, 17)

America's federal government and colluding mainstream society have repeatedly sought to cast the Native people of this continent as "the timeless negative of the nation's own self-evident becoming" (Magdaleno 2000, 281). Thus, in deconstructing such oppressive stereotypes, or, as Vizenor would phrase them, "the manifest manners of scriptural simulations," purveyed by the texts of the dominant institutions, Native writers as "Postindian warriors" must subvert these formulaic images that portray Native Americans as an endangered species by supplanting them with images of a vibrant culture.

A salient exemplification of "manifest manners of scriptural simulations" is imparted by the federal government's dubious notion of blood quantum, which has been emphatically dismissed by legitimate scientific disciplines, such as genetics and biological anthropology, as a residuum of eugenics (Crawford 2001; Gonzales, Kertesz and Tayac 2007). With their ugly history as weapons of disenfranchisement and of enforcement by hostile federal authorities, blood quantum rules as the only officially sanctioned definition of indigeneity have also been repudiated by those Native critics who deem them instruments of White oppression and divisiveness (Forbes 2021). For instance, the high degree of intermarriage between tribes of neighboring reservations, and especially among urban Indians, has split many families into oppositional camps of enrolled versus non-enrolled members. Since the federal government refuses to sanction enrollment in more than one tribe, persons with multiple tribal backgrounds whose blood quantum fractions may add up to near full blood totals, are frequently denied membership in any single tribe for not meeting its minimum blood quantum (Landry 2017). In addition, a particularly menacing development which has surfaced primarily among casino tribes in the past couple of decades amounts to the redrawing of blood quantum boundaries for the express purpose of disenrolling certain members, solely to exclude them from the redistribution of income from gaming.

Be that as it may, in his memoir, Momaday unequivocally deflates and subverts the "manifest manners" of official racial categorization not only by embracing his own Indian blood quantum but also by imposing upon it a symbol of Survivance. His undermining of this contested signifier surmounts a government as well as a condoning mainstream society in which tribal traditions have been devalued, leaving many Indians with conflicting reference points and often without a sense of stability. Yet, even while facing such a hostile sociocultural environment, Momaday demonstrates vigorously the plausibility of creating an ordered reality through introspection and the imaginative reconstruction of his tribal past as a viable orientation in the present. In an interview with Matthias Schubnell, Momaday characterized that cognitive process as fashioning his life "out of words and images ... that's a way of ordering one's life ... that's a way of making life acceptable to oneself" (Schubnell 1985, 44). 
In drawing attention to the Indian blood quantum on his birth certificate as a signifier of personal as well as tribal survival and resistance, Momaday frames its relevance with the following remarks:

"At four o'clock on the morning of February 27, 1934, in the Kiowa and Comanche Indian Hospital at Lawton, Oklahoma, near the old stone corral at Fort Sill, where my ancestors were imprisoned in 1873 for having fled to the last Buffalo range in the Staked Plains, I was delivered into the world by an elderly Indian Service doctor who entered my name on the Standard Certificate of Birth as Novarro Scotte Mammedaty ("Momaday" having first been entered, then crossed out)." (Momaday 1976, 41)

Imprisoned in the old stone corral, this band of Kiowas with their Comanche allies, led by Quanah Parker, himself the half-blood son of the White captive Cynthia Parker and the Comanche chief Peta Nocona, accounted for the last holdout of free Southern Plains Indians to be defeated by the US Army and forced onto a reservation in Oklahoma. Among those heroic forebears figured Maman-ti, a prominent Kiowa war leader and shaman, who died in exile in a military prison in Florida and whose name resembles the spelling of Momaday's ancestral family name, which on the birth certificate supersedes its simplified modern version (Texas State Historical Society 2021). Those events and personages are iconic in Kiowa and Comanche oral history, and Momaday's recalling them in conjunction with his birth in an Indian Service hospital named after the two tribes not only confirms his roots in the homeland but also serves as a powerful symbol of Survivance. In a twist of irony and defiance, the elderly doctor, who undoubtedly had labored among Indian people for many years and who, like numerous other early reservation physicians such as Drs. Washington Matthews and James Walker, may have been a passionate amateur ethnologist, was perhaps aware of Momaday's distinguished lineage and respected it enough to memorialize it in the archives of the oppressor.

The good doctor seems to have been equally considered in assigning the purported seveneighth blood quantum fraction, a critical signifier which has enabled Momaday to assert his Indian identity with the confidence of a full blood. Of equal magnitude as a signifier of indigeneity is Momaday's Kiowa tribal roll number, without which he would not have been officially classified as an American Indian and therefore would not have been eligible for federal and tribal services and benefits.

Was the blood quantum fraction possibly calibrated so infant Scott could qualify for tribal enrollment or was it merely a serendipitous error? A clue may lie in the way his mother, Mayme Natachee Scott, "presented herself" socially as well as officially. The birth certificate omits her first name and lists only her Cherokee middle name, Natachee, which in and of itself can certainly be interpreted as her assertion of an identity emphasizing her Native lineage. Though only oneeighth Indian, as the government would have classified her, and of pronounced European phenotype, as photographs of her in The Names clearly reflect, she nevertheless began to regard herself as an Indian during her rebellious teenage years. 
"That dim native heritage became a fascination and a cause for her, inasmuch, perhaps, as it enabled her to assume an attitude of defiance, an attitude which she assumed with particular style and satisfaction, it became her. She imagined who she was. This act of the imagination was, I believe, among the most important events of my mother's early life, as later the same essential act was to be among the most important of my own." (Momaday 1976, 25)

That attitude of defiance, which, in part, must have contributed to her progressive openmindedness regarding a marriage to a full blood Indian, demanded no small amount of courage in the brutally racist American mainstream society of the 1930s. Moreover, her act of the imagination may have prompted her to "present herself" as Indian not only socially but also officially, as may have been the case in imparting to her physician the requisite information for her son's birth certificate. Too distracted by his immediate focus on the parturition and the stress management of his patient, the good doctor perhaps simply estimated infant Scott's Indian blood quantum, possibly taking into consideration Natachee's "self-presentation." Thus, as Momaday seems to imply in appraising her pursuance of a Native identity as pivotal in her psychological development, it appears to have been paradoxically his one-eighth blood Indian mother who served as a model for the conception of his own sense of indigeneity.

\section{Concluding Remarks: Blood Memory as Survivance}

That Indian tribes and individuals wish to define themselves by seeking the approval of their oppressor, i.e., the federal government, might strike one as a great contradiction. However, what must also be considered is the common perception among Indian people of federal recognition as bestowing an official acknowledgement of tribal existence and survival. Treasured immensely by those who possess it, federal recognition is doggedly pursued by countless unofficial Native communities who, with only the slightest chance of success, will subject themselves to decades of bureaucratic reviews of requisite genealogies and historical documents. Hence, the Bureau of Indian Affairs' reluctance to grant recognition to most applicants, coupled with its much-feared past policy of terminating the federal reservation status of smaller tribes, has been excoriated as a continued form of ethnocide, even if the rejections amount to little more than decisions driven by the budgetary constraints within the US Department of the Interior.

Yet, for Momaday the semiotics of blood quantum moves far beyond its role as a signifier of "officially" recognized Indianess by appealing to the notion of racial memory.

"I think that each of us bears in his genes or in his blood. . a recollection of the past. Even the very distant past. . In the case of the Kiowa, it's a remembering of the migration. . . A remembering of crossing the Bering land bridge." (Woodard 1989, 21)

Contemplating tribal descent as an affective orientation, Momaday invokes through emotional transubstantiation a connection with the past as experienced in the present. This provocative juxtaposition of blood and memory issues a bold rejection of governmental pseudoscientific taxonomies of race by legitimizing tribal and personal narratives to surmount 
the history controlled by the colonizer. At least in the context of Momaday's introspection, memory in the blood engenders a refiguring of blood quantum into schemata which access the ancestors' mythic tales and thereby subverts the divisive bureaucratic instrument for the calculation of dubious fractions. Thus, Momaday's notion of mythopoetic memory in the blood appropriates as well as transforms the oppressor's construct of blood quantum into a signifier of personal and tribal Survivance.

\section{Conflict of Interest Statement}

The author declares no conflicts of interest.

\section{About the Author}

Guillermo Bartelt is a sociolinguist with a focus on the English varieties of American Indians at the spoken as well as written levels.

\section{References}

Charles, Jim. Reading, Learning, Teaching N. Scott Momaday. New York: Peter Lang, 2007.

Crawford, Michael. The Origins of Native Americans: Evidence from Anthropological Genetics. New York: Cambridge University Press, 2001.

Forbes, Jack. “The Blood Grows Thinner: Blood Quantum, Part 2." University of California, Davis, September accessed 27, 2021, https://web.archive.org/web/20100610050121/http://nas.ucdavis.edu/Forbes/Blood Qua ntum II.html

Goffman, Erving. The Presentation of Self in Everyday Life. Garden City, NY: Doubleday, 1956.

Gonzales, Angela, Judy Kertesz, Gabrielle Tayac. "Eugenics as Indian Removal: Sociohistorical Processes and the De(con)struction of American Indians in the Southeast," The Public Historian 29, no. 3 (2007): 53-67.

Landry, Alysa. "Paying to Play Indian: The Daws Rolls and the Legacy of \$5 Indians," IndianCountryToday.com, March 27, 2017.

Magdaleno, Jana Sequoya. "How (!) is an Indian? A Contest of Stories, Round 2" in Postcolonial Theory and the United States: Race, Ethnicity, and Literature, edited by Amritjit Singh and Peter Schmidt, 279-99. Jackson: University of Mississippi Press, 2000.

Momaday, N. Scott. The Names: A Memoir. Tucson: University of Arizona Press, 1976.

Schubnell, Matthias. N. Scott Momaday: The Cultural and Literary Background. Norman: University of Oklahoma Press, 1985.

Spruhan, Paul. A Legal History of Blood Quantum in Federal Indian Law to 1935. Social Science Electronic Publishing, 2001. https://papers.ssrn.com/sol3/papers.cfm?abstract id=955032

Tallbear, Kimberly. "DNA, Blood, and Racializing the Tribe". Wicazo Sa Review, 18, no 1 (2003): 81-107.

Texas State Historical Society, "Maman-ti," accessed September 27, 2021, https://www.tshaonline.org/handbook/entries/maman-ti 
Thornton, Russell. Tribal Membership Requirements and the Demography of "Old" and "New" Native Americans. Washington DC: The National Academy Press, 1996.

Vizenor, Gerald. Manifest Manners: Narratives on Postindian Survivance. Lincoln: University of Nebraska Press, 1994.

Woodard, Charles. Ancestral Voice: Conversations with N. Scott Momaday. Lincoln: University of Nebraska Press, 1989.

Author(s) will retain the copyright of their published articles agreeing that a Creative Commons Attribution 4.0 International License (CC BY 4.0) terms will be applied to their work. Under the terms of this license, no permission is required from the author(s) or publisher for members of the community to copy, distribute, transmit or adapt the article content, providing a proper, prominent and unambiguous attribution to the authors in a manner that makes clear that the materials are being reused under permission of a Creative Commons License. Views, opinions and conclusions expressed in this research article are views, opinions and conclusions of the author(s). and European Journal of Literature, Language and Linguistics Studies shall not be responsible or answerable for any loss, damage or liability caused in relation to/arising out of conflicts of interest, copyright violations and inappropriate or inaccurate use of any kind content related or integrated into the research work. All the published works are meeting the Open Access Publishing requirements and can be freely accessed, shared, modified, distributed and used in educational, commercial and non-commercial purposes under a Creative Commons Attribution 4.0 International License (CC BY 4.0). 